\title{
BIBECHANA
}

\section{Studies on molluscs of Betna wetlands and its surroundings, Nepal}

\section{Damodar Thapa Chhetry*}

Department of Zoology, P.G. Campus (Tribhuvan University), Biratnagar, Nepal Article history: Received 10 October 2010; Revised 11 November 2010; Accepted 13 November 2010

\begin{abstract}
This paper deals with 15 freshwater and 1 terrestrial mollusc species collected from Betna wetland and its surroundings. Among the collected 16 species, 12 species were gastropods representing 3 orders, 6 families, 8 genera and 4 species were bivalves representing 1 order, 2 families and 2 genera. Seven species of the total species of molluscs were edible and consume by the local people and 3 species were harmful.
\end{abstract}

\section{Key words: Molluses diversity; Betna wetland}

\section{Introduction}

The Betna wetland is located at Belbari Village Development Committee of Morang District. It extends between $26^{\circ} 20^{\prime}$ to $26^{\circ} 53^{\prime}$ lattitude and $87^{\circ} 16^{\prime}$ to $87^{\circ} 41^{\prime} \mathrm{E}$ longitude. It covers 5.5 hectors and receives natural water from its upper catchment area. Its surrounding area consists forest, small stream, little marsh area, paddy fields etc. Due to the presence of wetlands ( lakes) and other suitable habitats, it is rich in molluscan diversity. Regarding the diversity of molluscs, very few works has been done in Nepal. However, Subba and Ghosh [1,2] has made reports on molluscs of Nepal. Majupuria [3] has reported a few species of land and freshwater molluscs from Kathmandu valley. Investigation on different aspects of population dynamics of fresh water snails have also been carried out by Yadav et.al. [4], and Pfeiffer et. al. [5] Sharma [6] reported some species of molluscs from the various aquatic systems of the Koshi river basin belt. Subba and Pandey [7] studied molluscan diversity of Jhapa district of Nepal and reported 17 species freshwater and 4 species land molluscs. Subba and Ghos [8] reported 9 species of terrestrial molluscs from eastern, mid- eastern and far western regions of Nepal.

\section{Materials and methods}

The freshwater molluscs were collected from Betna wetland (oxbow lakes), paddy fields, marshes area and stream while the land molluscs were collected from shady and moist places. The specimens were collected up to one year from July 2008 to June 2009. The molluscs were

* Corresponding author: Dr. Damodar Thapa Chhetry, Department of Zoology, P.G. Campus (TribhuvUniversity), Biratnagar, Nepal, Email:thp_damodar@rediffhotmail.com 
mainly collected by hand picking method and also with the help of nylon cloth net (40 meshes $/ \mathrm{cm}^{2}$ ), nylon scoop, forceps etc. The collected specimens were kept in polythene bags and plastic containers. Then the animals were preserved in $5 \%$ formalin for further study. Dead specimens with dry shells were also collected. Identifications were made according to Preston [9] Mellanby [10] and Subba Rao [11].

Table 1: Molluscs species of Betna wetlands and its surroundings

\begin{tabular}{|c|c|c|c|}
\hline Class & Order & Family & Scientific name \\
\hline Gastropoda & Mesogastropoda & Pilidae & Pila globosa (Swainson, 1822) \\
\hline Gastropoda & Mesogastropoda & Pilidae & Pila theobaldi (Hanley, 1875). \\
\hline Gastropoda & Mesogastropoda & Thiaridae & Brotia costula (Rafinesque, 1833) \\
\hline Gastropoda & Mesogastropoda & Thiaridae & Thiara punctata (Lamark,1822) \\
\hline Gastropoda & Mesogastropoda & Thiaridae & Thiara tuberculata (Mullar,1774) \\
\hline Gastropoda & Mesogastropoda & Thiaridae & Thiara granifera (Lamark,1822) \\
\hline Gastropoda & Mesogastropoda & Viviparidae & Bellamya bengalensis (Lamark,1882) \\
\hline Gastropoda & Basommatophora & Lymnaeidae & Lymnaea luteola (Lamark, 1822 ) \\
\hline Gastopoda & Basommatophora & Lymnaeidae & Lymnaea acuminata (Lamarck, 1822) \\
\hline Gastropoda & Basommatophora & Planorbidae & $\begin{array}{c}\text { Indoplanorbis exustus (Deshayes, } \\
1834 \text { ) }\end{array}$ \\
\hline Gastropoda & Basommatophora & Planorbidae & $\begin{array}{c}\text { Gyraulus convexiusculus (Hutton, } \\
1849 \text { ) }\end{array}$ \\
\hline Gastropoda & Pulmonata & Stenogyridae & Achatina fulica. \\
\hline $\begin{array}{c}\text { Bivalvia } \\
\text { (Pelecypoda) }\end{array}$ & Unionoida & Unionidae & $\begin{array}{c}\text { Lamellidens marginalis } \\
\text { (Lamark,1819) }\end{array}$ \\
\hline $\begin{array}{c}\text { Bivalvia } \\
\text { (Pelecypoda) }\end{array}$ & Unionoida & Amblemidae & Parreysia favidens (Benson, 1862) \\
\hline $\begin{array}{c}\text { Bivalvia } \\
\text { (Pelecypoda) }\end{array}$ & Unionoida & Amblemidae & $\begin{array}{l}\text { Parreysia caerulea gaudichaudi } \\
\text { (Eydoux, 1838) }\end{array}$ \\
\hline $\begin{array}{c}\text { Bivalvia } \\
\text { (Pelecypoda) }\end{array}$ & Unionoida & Amblemidae & Parreysia caerulea (Lee, 1831$)$ \\
\hline
\end{tabular}

\section{Results and Discussion}

Altogether 16 species of molluscs belonging to 2 classes, 4 orders, 8 families and 10 genera were identified (Table 1). Among 16 species, 12 species were gastropods representing 3 orders, 6 families, 8 genera, and 4 species were bivalves representing 1 order, 2 families and 2 genera (Table 1). Seven species of the total species of molluscs were edible and consume by the local people (Table 2) and 3 species were harmful (Table 3). Among three species, Achatina 
fulica is more harmful, it destroys all types of plants. Among the collected species, Bellamya bengalensis and Lymnaea acuminata were found abundantly in the study area.

Table 2: Edible molluscs of Betna wetland and its surroundings

\begin{tabular}{|c|l|l|}
\hline S.N. & Name of the species & Tribes who eat molluscs. \\
\hline 1 & Pila globosa (Swainson, 1822) & Jhangad, Bantar, Sardar, Malaha etc. \\
\hline 2 & Brotia costula (Rafinesque, 1833) & Jhangad, Bantar,Sardar, Malaha etc. \\
\hline 3 & Bellamya bengalensis (Lamarck,1882) & Jhangad, Bantar, Sardar, Malaha etc. \\
\hline 4 & $\begin{array}{l}\text { Lamellidens marginalis (Lamarck, } \\
1819)\end{array}$ & $\begin{array}{l}\text { Jhangad, Bantar,Sardar, Malaha, } \\
\text { Choudhary etc. }\end{array}$ \\
\hline 5 & Parreysia favidens (Benson, 1862) & Jhangad, Bantar, Sardar, Malaha, etc. \\
\hline 6 & $\begin{array}{l}\text { Parreysia caerulea gaudichaudi } \\
\text { Eydoux, 1838) }\end{array}$ & Jhangad,Bantar,Sardar, Malaha, etc. \\
\hline 7 & Parreysia caerulea (Lee,1831) & Jhangad, Bantar, Sardar, Malaha, etc. \\
\hline
\end{tabular}

Table 3: Harmful molluscs of Betna wetland and its surroundings

\begin{tabular}{|c|c|c|}
\hline S.N. & Name of the species & Harmful activities \\
\hline 1 & $\begin{array}{c}\text { Bellamya bengalensis } \\
\text { (Lamarck,1882) }\end{array}$ & Pest of seedlings of paddy \\
\hline 2 & $\begin{array}{c}\text { Lymnaea acuminata (Lamarck, } \\
1822 \text { ) }\end{array}$ & Intermediate host of Liverfluke. \\
\hline 3 & Achatina fulica & Destroy vegetatable and crop pest. \\
\hline
\end{tabular}

\section{References}

[1] B. R Subba and T.K Ghos , J. Bombay Nat. Hist. Soc. 97(2000):452.

[2] B. R. Subba and T.K. Ghos, J. Bombay Nat. Hist. Soc. 97(2001)58.

[3] T.C. Majupuria, Wild is Beautiful: Introduction to fauna and Wildlife of Nepal. S. Devi, Gwalior, India, (1981- 82) p. 507.

[4] U.K.R Yadav, S.B. Karki, and P.N. Mishra, J. Nat. His. Mus. 4(1980)33.

[5] M.P.Feiffer,S. Sharma andB.M.Dahal,Proc. of IIINat. conf. on Sci. and Tech. Nepal,(1999)1371.

[6] U.P. Sharma, Ecological Society (ECOS), Kathmandu, Nepal (1996) 92.

[7] B.R. Subba and M.R. Pandey, J.Nat. Hist. Mus. 22(2005) 22.

[8] B.R.Subba and T.K. Ghos J.Nat. Hist. Mus. 23 (2008) 78.

[9] H.B. Preston, The Fauna of British India including Ceylon and Burma, Taylor and Francis, London(1915).

[10] H. Mellanby, Animal Life in Freshwater, Methuen and Co., London (1963).

[11] N. V. Subba Rao, Handbook of Freshwater Molluscs of India, Zoological Survey of India , Calcutta(1989). 